\title{
Visual-Based Representation and Mediation in Digital Culture Impacts Political Participation, Issue Advocacy and Campaigning for Social Change
}

\author{
Stephen T. F. Poon
}

\begin{abstract}
With rapid evolution of each successive system of global information technology, corporations and governments today battle to exert economic, political and cultural power. Media such as the Internet and social networks have emerged as 21st-century public commons that broadcasts and channels communication in social, communal and commercial interests, and more recently, to mediate the world of politics. The role of visual-based digital culture as an interactive medium would be explored in this paper, with qualitative case studies discussing the processes and means whereby political messages and issues are effectively mediated into meaningful communication. This paper considers the complexities of balancing political discourses in the climate of media infusion that characterises today's digital culture; and the shaping of democratic ideals utilising visual representation and mediation. Recent political activism in Malaysia will be analysed to understand the citizen journalist's role in supplying and impacting society with dynamic digital communication tools. Case study examples of social media-fuelled issue advocacy will be discussed to understand the role of visual communication as enabler for political campaign supporters to distinguish themselves. The paper concludes by pondering if digital media tools have become the tool of choice for citizenship activism and political advocacy among Malaysians.
\end{abstract}

Index Terms-Advocacy, citizen journalist, social networks, social media, visual communication.

\section{INTRODUCTION}

The roles of globalisation and technology have been exhaustively researched by academia, global thought leaders and the media. Alongside activism for causes like conservation, environmental awareness and consumerism, contemporary societies are broadening the range, while blurring the authenticity, of textual information on media [1]. If traditionally, units of industrial economy were socially differentiated by the location of workers to the network nodes - the concept of 'informational space flows' attributed to Manuel Castells [2], a form of counter-culture, notes Gere [3], had begun developing in the 1990s as information was digitally communicated and reproduced. Via screens, web channels, networks and publications, new media could openly transmit data as they continue to seek global audiences increasingly disenchanted with capitalist dominance, yet hungry for continual feeding of images of social, cultural, environmental and economic concerns. However,

Manuscript received January 19, 2015; revised April 9, 2015.

Stephen T. F. Poon is with Taylor's University, Malaysia (e-mail: stephentfpoon@aol.com). post-industrial society's interest in a political economy has since proven to be the kind that is "stripped of militaristic, technocratic aura, repainted with a gloss of cybernetic idealism (...) and repurposed as a gentler, kinder tool", to conceive of the world they had inherited [3], post-Cold War. Such mediated forms of self-conception and of worldview, argue globalisation thinkers, could not be considered sustainable for all sectors in society, since informational resources concentrate within urban networks of financial, economic, scientific and cultural news [2], [4].

\section{A. A Globalised View of Mediated Political Advocacy}

John Urry, writing at the turn of the millennium about the unbridling of citizenship in the new global social order, commented that in the age of globalisation, commercial media and cultural institutions had become essential tools of quasi-interaction beyond state and citizens. By extension, vehicles such as advertisements, media images and other highly-visible forms of cultural productions (e.g. globally broadcast arts, sporting or political events) were being pressured to serve public interests transnationally [4]. The citizen engages in a culturally differentiated, media-infused environment, where the images, icons, textual narratives merge people into 'collective identities of shared interests rather than citizens of a nation, class or generation' [4]. Uncontrolled information flow may only be trusted at a superficial level, hence owners of information (e.g. political) may run against official institutions in their aim to gather data or funds, or to persuade others about their agendas such as organising rallies, movements and protest groups [1].

Margaret Scammell [5], writing in Political Communication, foretold at the dawn of mass World Wide Web acceptance, the keen corporate interest in the potential of the Internet. Web-based technologies determine how classes of 'citizen consumers' as described by Scammell legitimised in their civic concern with consumer education in seeking goods and information - participate in public-spirited critique of consumption and this, she believes, implies the politicisation of consumption itself. Just as inescapable, perhaps, is the visible parallel growth by the burgeoning use of the Internet among citizen journalists. The citizen journalist is defined by Morris and Goldsworthy [6] as 'a member of the public - as opposed to a trained, salaried journalist - who uses the Internet or blogs to report and comment on current and business affairs ... [and may also take] photographs or film of key events'. Connecting at strikingly instantaneous speeds previously unavailable, citizen journalists such as bloggers and activists take on an 
increasing political edge use social networking tools to shape opinions and unfold the 'diversity and richness' [1] of news once controlled by political masters, besides updating their followers on political issues of national or local concerns [7].

In recent years, Afghanistan, Egypt, Iraq, Pakistan, Syria, United States and Russia have seen the domestic restructuring of internal political systems because of the impact of mediated events. Barack Obama mobilised drive and support of ground organisers and volunteers for his Presidential campaign in 2008 with social networking and new media forms [8]; pre-election campaigning for Finland's parliamentary election of 2007 were conducted and shared via YouTube [1]; Icelandic citizens in 2013 were able to debate openly via Facebook and Twitter on aspects of constitutional draft changes [9].

\section{LITERATURE REVIEW}

By 2011, Malaysia had totalled 17.5 million Internet users, of which five million were broadband-enabled, 2.5 million having wireless broadband, and ten million, $3 \mathrm{G}$ subscribers [10]. With over 28.7 million in local populace [11], it is clear that the number of Malaysian Internet users had risen to more than half of the population. Malaysia's boom in the information and consumption economy has kept pace with developing nations around Asia. As people migrate to the information-centric spaces of a corporate (rather than state-controlled or political) economy, various efforts at marshalling political reformation through citizen participation have occurred, creating a sense of belonging among the socio-cultural segment called netizens ('Internet Citizens'). Digital access help individuals and communities relate to significant events such as general elections and public referendums in their common denomination, i.e. that they are no longer distant affairs. The Internet has become the fastest way of getting updated news as they happen in real time. Whether publishers, users or consumers of information, the extraordinary influence of social media as constantly-shifting cultural capital mean netizens see themselves as members and enablers in transforming the nature of events themselves [Staehle, cited in 3:208]. Facebook, YouTube, Blogspot.com, Twitter, and Linkedin.com are some of the popular social networking services that have enabled Malaysians from all walks of life working professionals, minority groups, rural segments, the disabled, youth, senior citizens, etc. - to participate in the realm of social media.

\section{A. Social Media Fuel for Political Reformation in Malaysia in the Age of Web 2.0}

Alexa web metrics affirmed the popularity of certain websites among Malaysians, ranging from news portals to online marketplaces and shared content sites [12]. SocialBakers, a social media analytics company, ranked Malaysia 17th among 213 nations for the most Facebook users, while time spent on social networking s almost 2 hours per week [13], [14]. Besides one-to-one communication, social media in Malaysia is a potential channel for marketers to respond to local consumers' needs and engage them with brand messages [15]. Malaysia's 12.4 million Facebook users are almost on par with the total number of its Internet users proving that a vast number of Malaysians are avid adopters of web technology and social networking. Yet online usage and user segments are as hard to track as they are to target, and some have accused Malaysians of gullibility in buying or trusting online information.

In the political sphere, digital communication has migrated into the folds of being preferred, mainstream media channels in Malaysia [16]. Free-to-air television and radio channels are government-owned or controlled by the parties in the ruling coalition, and tend to present biased reports in the context of mediated favour towards the coalition in power [17].

This evidently did not stop the 'fair, free and clean election' citizens' movement known as Bersih to ripple around the world on the basis of "spontaneous expressions of patriotism" among communities of Malaysians [18].

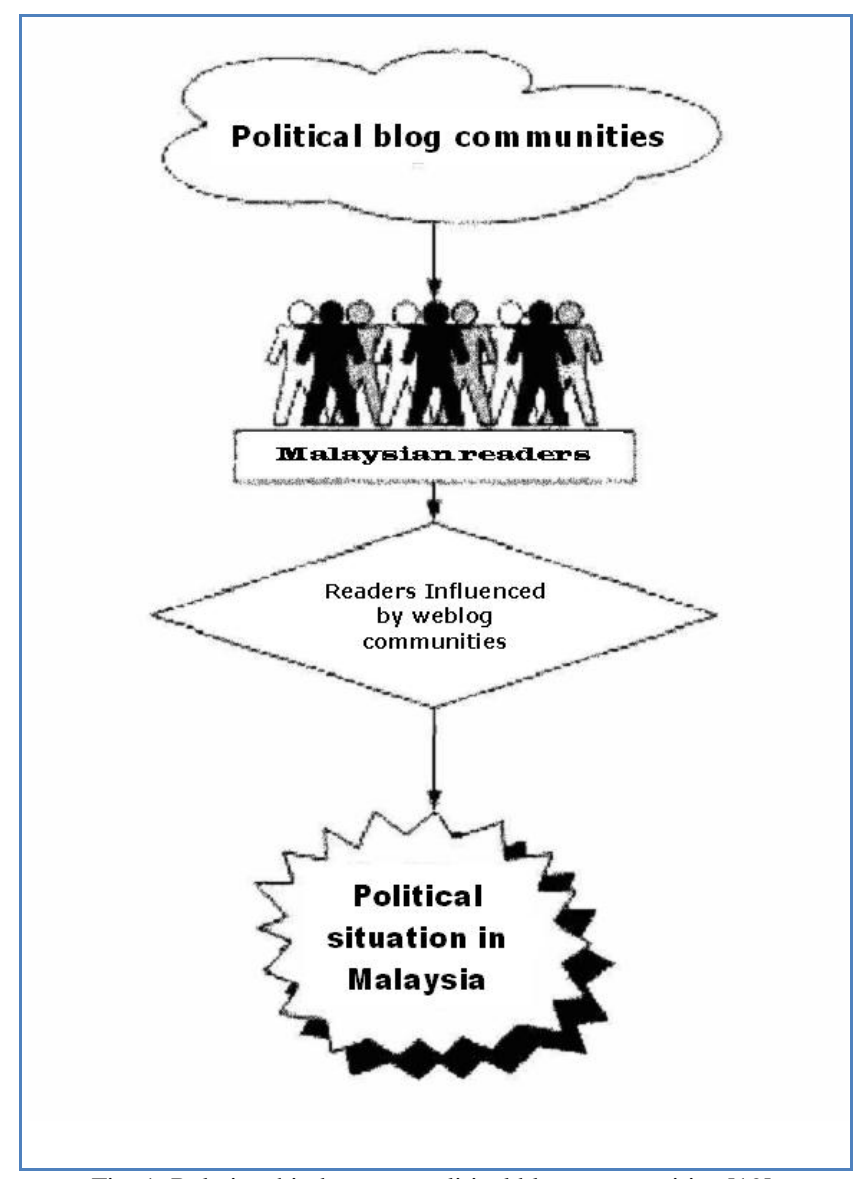

Fig. 1. Relationship between political blog communities [19].

Aside from building a spirit camaraderie among supporters [20], the Bersih campaign rallies were deemed successful efforts by locals for spurring citizen journalists could also be known as Political Blog Communities to provide informed choices by spreading the contesting factions' manifestos and intentions to Malaysians working (Fig. 1), studying or living around the world leading to the 13th Malaysian General Election [18], [21]. Like a banner of recrimination, Bersih 2.0 agitated against the enactment of the Peaceful Assembly Bill 2011 and protested the government for vesting authority in the police to ban or otherwise restrict or disperse assemblies taking part in peaceful street demonstrations [22]. 
Social media such as Facebook, Twitter and YouTube played a big role in reporting current events that are not featured in government-controlled media. These virtual common spaces helped Bersih supporters to debate, share information and clarify conflicting news reports. The Facebook Bersih 2.0 official community page encouraged supporters to use PicBadges (Fig. 2) as their profile picture to support the campaign [23]. With over 238,000 likes, the movement proved its appeal before, during, and after the Bersih 2.0 rally.

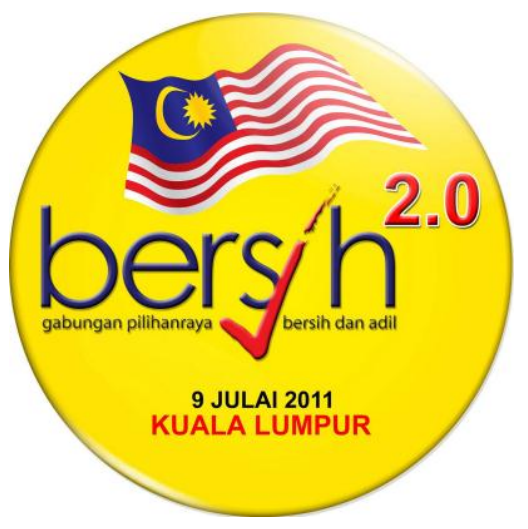

Fig. 2. PicBadge for Bersih 2.0 [24].

\section{RESEARCH METHODOLOGY}

To review the progress of visual communication in social media political advocacy campaigns efforts, this paper will discuss the functions and roles of social media in established political campaigns. The researcher sets out to demonstrate the importance of projecting new media as a tool to enhance visual representation and mediation. In view of foregoing assumptions, the objective behind this research is to examine the role of visual-based digital culture as an interactive medium, and how political messages are effectively mediated into meaningful communication. Qualitative case studies of social media-fuelled protests will be discussed to understand the role of visual communication as a tool that enabled campaign supporters to discern themselves. Interpretive analysis will be provided in the complexities of balancing political discourses in the climate of media infusion that characterises today's digital culture.

The key question: How has new media become the tool of choice for citizenship activism and political advocacy among Malaysians? Underscore the process of searching for answers.

\section{ANALYSIS AND DISCUSSION OF THE FINDINGS}

As development in culture, the economy and citizenship "crisscross public and private consumption spheres" [4], so too the infiltration of images, landscapes and icons from their appeal as interpretive discourse sites for contemporary social experiences and political thoughts [4]. Community pages on social media not only activate previously passive audiences to receive political messages, it gives them opportunities to participate in the political process and potentially change its course [1]. As Mahaney [25] explains, effectiveness come through the intended symbolism of the message - humorous, moralistic, patriotic, sentimental, or horror-inducing - the dense meaning layers must be evocative of a culture at a certain place and time. Easily digestible political advocacy is noted by media and culture researchers to have grown so impactful that power factions may recognise it as a threat. Thailand's red shirt protests and street demonstrations were perhaps a close peer inspiration for the Bersih rally, yet discourses unique to Malaysia may be found by studying the rehashing of mixed cultural elements in the politically-charged public spaces of traditional and social media.

\section{A. Riding the "Remix Revolution"}

Remix culture, according to University of Colorado's Prof Mark Amerika, a leading authority in virtual art, is the use of re-editing to remake an existing cultural text product into a new product [26]. Although the term "remix" was popularised in DJ paralanguage, its effects are now palpable in Web 2.0 discourses through mashups distributed via video, Internet art, audio art and more [26]. In its political context, remixing imageries or textual discourse helps audiences associate with key concepts of the political message or information. A closer analysis of Malaysian protestation graphics find symbolic images derive from popular or existing images, rehashed and given interpretive sense from a local viewpoint.

"KillTheBill" was a virally-circulated poster on social media that blazed the trail for a civic movement after the enactment of the Malaysian Peace Assembly Bill in 2011 [27]. Its name and design is ripped from the American movie, Kill Bill, a story of betrayal and revenge. The bill in question bans all demonstrations unless approved by the police, allowing the latter to determine cultural and religious grounds for refusal to approve public gatherings [28], while giving the Home Minister "more powers (...) aimed at stifling democratic space" [20]. The poster's rich yellow patina signifies symbolic association with the hallmark objectives of the Bersih 2.0 rally and its peaceful mode of urging for electoral practice reforms.

"KillTheBill" is apt as the rehashed design helps local society deal intelligently with unreasonable power-mongers, while finger-pointing the divided political situation to authorities they deem difficult to trust. This poster illustrates how the public decodes perceptions of rights suppression and how social media activates participatory dialogue through netizens' interaction.

Sloganeering is upturned in one community page that calls for the resignation of the Malaysian Prime Minister [29]. Depicted in speechmaking mode, the minister's face is slashed with a bright yellow " $\mathrm{X}$ ", while protestation is represented by a yellow border and his attire (gold) - all recurrent schemes that make reference to the Bersih campaigns. Liking the page may indicate visual appeal, yet it is more apparent that the act of sharing political ideologies using buffoonery is nearly always an indirect criticism of the current government and the disproportionate balance of power in regards to giving voice to non-partisans and opposition party supporters.

Participation in online social protest steamrolls enthusiasm, the furore rose against the Malaysian Tourism Ministry for 
spending RM1.8 million to create several Facebook apps to promote its travel and tourism programme [30], was an interesting instance. Some started critically examining the topic from merely having friends and contacts reciprocating and expressing opinions, hence stoking an informal sort of "public uprising" via social media, as denounced by the administrators of Curi-Curi Wang Malaysia (literally, stealing Malaysia's money):

We can prove to government we no need to spend RM1.8M for a success fan page. We want our mismanaged money back! This page created with purpose to voice against Malaysia Tourism Ministry who spent RM1, 758, 432 for a simple Facebook fan page with 6-simple apps (cost RM293,072 each). "Facebook is FREE. Don't cheat our money in such stupid way and treat us like idiots. Suspend the contract and RETURN OUR MONEY!!

The profile picture of Curi-Curi Wang is derived from the design of Cuti-Cuti 1 Malaysia [31]. Their pronunciation resemblance was a purposeful tactic: $c u t i$ (vacation) replaced with curi (steal). The difference is the graphic used in the Curi-Curi Wang profile picture. Two fifty-sen coins next to the visual graphic of 'Malaysia' signify questions about the ethical governance of local taxpayers' money. Perdana Putra, the domed headquarters of the Prime Minister's Department, appears above the slogan, and the image of two swallows against a yellow background suggests the government is “swallowing" citizens' money. Curi-curi Wang drew 121,000 likes in under a week, while Cuti-Cuti 1 Malaysia had 35,000 likes in a month's span [32]. This send-up is a good example of intelligent protest discourse, the design reflects the site owner's stance even as it mocks Malaysia's long term tourism programme.

\section{B. The "Exchange" Factor in Social Media Revolutions}

The use of social media to remix political imageries, commentaries and opinions has gained the interest of citizens who struggle to dislocate propaganda through sense-making and consumption of advocacy messages via cultural sources such as Internet news sites and community pages.

Citizen consumers today use their knowledge to achieve a certain political leverage, and this is increasingly shown in their ability to affect particular political situations and bring about change, or instigate talk of change [33]. This reflects the findings by Quan-Haase et al. [34] in The Internet in Everyday Life, whereby social classes are noted to be divided by their political participation, and discussion of politics is a social activity among engaged 'information seekers' in a literate society - an argument attributed to Castells' "networked society" thesis.

In that sense, the parallels between economic and political consumption have started to converge: what politicians and parties offer the citizen-consumer, as Scammell [5] states, is "inherently reciprocal" - the recipient audience must listen attentively to what's offered in order to process new information and gain the benefit of knowing before being included into the conversation stream [35].

Networking is a participatory activity that requires neither capital nor membership. While many factors shape and shift media habits, members of the older generations are seen to be more wisely attuned to the complicities of media space. Among the younger generations, as social thought and behaviour are revolutionised through shared media spaces, a heightened interest in the development of political ideologies and public activism results [36].

An example is in the 100,000 People Request [Malaysian Prime Minister] Najib Tun Razak Resignation Facebook page which - while puerile and bigoted for some, drew comments mainly from youths [29]. The post, directed at other youths, applies informal language and enables users to see each other's profile pictures. Spoofing and appraisal of the political situation takes place comfortably in Manglish medium (atrocious mangling of Malay words with English), internet languages and clipped form of Bahasa Melayu, the page owner expresses in nuanced slang terms: "epic" and "fail", for instance, are typical of words used to describe something outrageously funny. Gen-Y's preference for political information and views delivered, communicated and exchanged via networking sites conforms to their pre-existing political views [35], redefining the media and graphic communication forms for social learning, participation, and may ultimately decide or shape their potential involvement in politics.

\section{CONCLUSION}

"Campaigns are becoming more individualised (...) more mobile to adapt to changes in the political environment."

- Richard Semiatin [37]

Being left behind seems no longer an option in the new media age, and Malaysians both within the country and abroad are affected, as technology enables immediate glimpses of the evolutionary players and historic events driving change through political campaigns. Sans social media, discourse involving future generations of change-makers could not have been possible. Political imagery, communicated using specific colours and tacked onto intelligent design, showed the tremendous capacity of social movements to influence mind sets in its role as connectors and information hubs, giving voice to a live outpouring of reformation-minded Malaysians to think, talk and work out ideas surrounding untenable political issues, corrupt electoral processes and governance issues which they claim has crippled the nation. Awareness of the government's firm reign over mainstream media, along with the ease which visual communication in the form of visceral, symbolic representations such as colours, designs and identifiable local elements piques audiences' keen gaze, has inadvertently popularised and redefined how protestation is viewed.

As the nation appropriates alternative discourses aimed at improving and maturing nation-building efforts, what seems obvious is that the younger generation of Malaysians today perceive citizenship as no longer the sole domain of an educated, urbane generation, but that in politics, the boundary-blurring effects of technology and social media provides fair game to every candidate, incumbent, electioneering party and bloc vying for their attention and vote. 


\section{REFERENCES}

[1] Centre of European Studies. (July 18, 2014). Social Media - The New Power of Political Influence. Helsinki: Suomen Toivo Think Tank. [Online].

available:

http://martenscentre.eu/sites/default/files/publication-files/kansio-digi tal_democracy_-_final_en.pdf

[2] M. Castells, The Power of Identity, The Information Age: Economy, Society and Culture, vol. 1, Malden, MA: Oxford UK: Blackwell, 1996.

[3] C. Gere, Digital Culture, London: Reaktion Books Ltd UK, 2008.

[4] J. Urry, "Globalisation and citizenship," Journal of World-Systems Research, vol. 5, no. 2, pp. 311-324, 1999.

[5] M. Scammell, "The internet and civic engagement: Age of the citizen consumer," Political Communication, vol. 17, pp. 351-355, 2000.

[6] M. Morris and S. Goldsworthy, PR Today: The Authoritative Guide to Public Relations, Hampshire, UK: Palgrave Macmillan, 2012.

[7] E. Yapp, Popular Malaysian Blogger Turns Politician, ZDNet, July $31,2007$.

[8] C.C. Miller, "How Obama's internet campaign changed politics," The New York Times, November 7, 2008.

[9] H. Landemore, "We, all of the people," Slate Magazine, July 31, 2014.

[10] Malaysian Wireless. (February 2014). Malaysia: 17.5 Million Internet Users, 5 Million on Broadband, 10 Million on 3G. [Online]. Available: http://www.malaysianwireless.com/2011/06/malaysia-broadband-3gusers/

[11] Index Mundi. (May 2014). Malaysia demographics profile. [Online]. Available: http://www.indexmundi.com/

[12] Alexa. (June 2014). Top Sites in Malaysia. [Online]. Available: http://www.alexa.com/topsites/countries/MY

[13] The Star Newspaper, "250,000 kids on Facebook even with age restriction," July 1, 2012.

[14] The Star Newspaper, "Internet facts," November 17, 2012.

[15] Advertising \& Marketing, Standing out in a Social Crowd, Kuala Lumpur: Lighthouse Independent Media, 2012, pp. 46-49.

[16] The Next Web. (September 17, 2011). Social media in Asia-Pacific. It's BIG and Facebook dominates. [Online]. Available: http://thenextweb.com/socialmedia/2011/09/17/social-media-in-asiapacific-its-big-and-facebook-dominates/

[17] Taipei Times, "Malaysian election chief speaks against media bias," February 24, 2008.

[18] Global Bersih 2.0. (July 2014). The awakening of the Malaysian diaspora. [Online]. Available: http://www.globalbersih.org/locations/global-bersih-2-0/global-bersih -2-0-the-awakening-of-the-malaysian-diaspora/

[19] M. N. A. Nasir, A. Selamat, H. Selamat, and M. Z. A. Zaidi, "Relationship between political blog communities, Malaysian readers and political situation in Malaysia," The Dominant of Bloggers in Malaysian Politics through Social Networks, Faculty of Computer Science \& Information System, pp. 228-224, 2008.

[20] T. Yeoh, "Lesson in social media from Bersih 2.0," The Nutgraph, September 12, 2011.

[21] YouTube. (July 9, 2011). Bersih 2.0 Worldwide (online video). [Online]. http://www.youtube.com/watch?v=JZyLYFXobk0

[22] The Malaysian Bar. (November 26, 2011). FAQs on Peaceful Assembly Bill 2011. [Online]. Available: http://www.malaysianbar.org.my/constitutional_law_committee/faqs_ on_peaceful_assembly_bill_2011.html

[23] Facebook. Bersih 2.0 (Official). (July 2014). [Online]. Available: https://www.facebook.com/BERSIH2.0OFFICIAL?fref=nf

[24] PICBADGES. (February 2012). PicBadges Website for Bersih 2.0. [Online]. Available: http://www.picbadges.com/bersih-2/1743665/

[25] D. C. Mahaney, "Propaganda posters," OAH Magazine of History, vol. 16, no. 3, pp. 41-46, 2002.
[26] M. Amerika, Remixthebook, Minneapolis: University of Minnesota Press, 2011.

[27] S. S. Maria, "Last chance to kill assembly bill," Free Malaysia Today, December 15, 2011.

[28] S. Teoh. (December 2011). Assembly law restricts religious freedom, says interfaith group. The Malaysian Insider. [Online]. Available: http://www.themalaysianinsider.com/malaysia/article/assembly-law-r estricts-religious-freedom-says-interfaith-group

[29] Facebook. (August 2014). 100,000 People Request Najib Tun Razak Resignation. [Online]. Available: https://www.facebook.com/pages/100000-People-Request-Najib-Tun -Razak-Resignation/223344854372583?sk=photos_stream

[30] The Malaysian Insider. (June 14, 2011). Tourism Ministry RM1.8m spent on Facebook pages. [Online]. Available: http://www.themalaysianinsider.com/malaysia/article/tourism-ministr y-rm1.8-million-spent-on-facebook-pages/

[31] Facebook. (July 2014). Curi-Curi Wang Malaysia. [Online]. Available: https://www.facebook.com/CuriCuriWangMalaysia

[32] Malaysian Tourism Watchdog. (June 20, 2011). Facebook Debacle. [Online]. Available: http://malaysiatourismwatchdog.blogspot.com/2011/06/facebook-deb acle.html

[33] Google Mei. (November 30, 2011). Kill The Bill - The Peaceful Assembly Bill Malaysia. [Online]. Available: http://googlemei.blogspot.com/2011/11/kill-bill.html

[34] A. Quan-Haase, B. Wellman, J. C. Witte, and K. N. Hampton, "Capitalising on the Net: Social Contact, Civic Engagement, and Sense of Community," in The Internet in Everyday Life, B. Wellman and C. Haythornthwaite, Eds. Oxford, UK: Blackwell Publishing Ltd, 2002.

[35] M. Scammell, Is Political Marketing All That Bad? January 29, 2014

[36] J. C. Baumgartner and J. S. Morris, "My FaceTube politics: Social networking web sites and political engagement of young adults," Social Science Computer Review, vol. 28, no. 1, pp. 24-44; 2009.

[37] R. J. Semiatin, Campaigns on the Cutting Edge, Washington, D.C.: CQ Press, 2008.

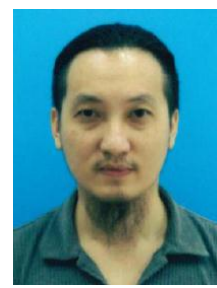

Stephen Poon was born in Melaka, Malaysia. He completed postgraduate studies at Hogeschool voor de Kunsten Utrecht, The Netherlands. He is a social design catalyst, as well as user experience analyst who has his own particular view of the world, worked and studied all over the Europe - United Kingdom, Germany, Spain, The Netherlands, Belgium and Czech of Republic. His multicultural background is reflected in Stephen's versatile approach and continuous interest in design, innovation and social change. In 2004 he returned to his homeland, moved into design education where he helped to cultivate new ambitious generation in design practice during his lectureship. He is actively in research, published in the scholarly journals, newsletters and magazines in design issues and debates on advertising, branding, built environment, product and creative media, contemporary critical and cultural debates across a wide range of arts and humanities fields.

$\mathrm{He}$ is an academic in The Design School at Taylor's University where he has been a faculty member since 2012 . He holds the lectureship for design research and contextualising practice.

Mr. Stephen has served on the organising committee for the $6^{\text {th }}$ Taylor's Teaching \& Learning Conference 2013 and Taylor's Research Fair 2013. He currently serves on the Executive Committee and Steering Committee for MINDS (Malaysia Invention \& Design Society) and the council member for MRM (Malaysian Design Council). 